\title{
A place in the Sun? IRENA's position in the global energy governance landscape
}

\author{
Indra Overland ${ }^{1}$ (D) Gunilla Reischl ${ }^{2}$
}

Accepted: 18 January 2018/Published online: 29 January 2018

(C) The Author(s) 2018. This article is an open access publication

\begin{abstract}
The International Renewable Energy Agency (IRENA), created in 2009, is the only intergovernmental organization dedicated to renewable energy. Drawing on several new datasets, this article explores IRENA in the context of three other major international energy organizations: the International Atomic Energy Agency, the International Energy Agency and the Organization of Petroleum Exporting Countries. Through this analysis, several empirical approaches to comparing international energy organizations are tried out. Direct comparison between IRENA other international energy organizations is found to be problematic as each organization is different and comparisons inevitably encounter apples and oranges type issues. The study finds that IRENA's niche in international renewable energy governance is not yet fully carved out, but that the organization's mandate and institutional structure, as well as recent international developments, indicate that it may grow rapidly in importance.
\end{abstract}

Keywords IRENA · Renewable energy - Energy governance - Global governance $\cdot$ IEA $\cdot$ OPEC $\cdot$ Energy transition · Organizational ecology

\section{Introduction}

International cooperation on renewable energy can be traced back to the UN Conference on New Sources of Energy, held in Rome in 1961 (Karlsson-Vinkhuyzen 2010). Since then, several mechanisms and networks dedicated to renewable energy have emerged, including the Renewable Energy Policy Network for the twenty-first century (REN21), the

Gunilla Reischl

Gunilla.reischl@ui.se

Indra Overland

ino@nupi.no

1 Norwegian Institute of International Affairs, PB 8159 Dep, 0033 Oslo, Norway

2 Swedish Institute of International Affairs, P.O. Box 27035, 10251 Stockholm, Sweden 
Renewable Energy and Energy Efficiency Partnership (REEEP) and the Clean Energy Ministerial (CEM) (Parthan et al. 2010; Florini and Sovacool 2009). In addition, several major international organizations, such as the EU, the G8, and the G20, have played active roles on renewable energy issues (Andrews-Speed and Shi 2016; Oberthür 2016; Downie 2015; Leal-Arcas and Filis 2013; Florini and Dubash 2011; Van de Graaf and Westphal 2011; Bazilian et al. 2010; Lesage et al. 2009). For overviews of the global governance of renewable energy, see Hirschl (2009) and Rowland (2005).

However, IRENA is the first intergovernmental organization exclusively focused on renewable energy. Over the years, various proposals for creating an international organization for renewable energy had been tabled, but it was not until 2009 that the decision was finally made to establish such an organization. IRENA came into physical existence in 2011, with headquarters in the United Arab Emirates. Membership is open to all UN member states. Despite rapid growth in the number of member states, there was initial skepticism toward IRENA. Some states did not see any need for a new international energy organization, whereas others had reservations about the promotion of renewable energy. For detailed accounts of the politics leading up to the founding of IRENA, see Röhrkasten and Westphal (2013) and Van de Graaf (2013a, b).

The creation of IRENA was actively promoted by the same German actors who were behind Germany's Energiewende, seeking to scale up the national energy transition to the global level. The organization's setup is largely consistent with the original German proposals (Röhrkasten and Westphal 2013: 3; Federal Foreign Office 2014). IRENA consists of three main bodies: the Assembly, which its highest decision-making body with one representative from each member state; the Council, which is subordinate to the Assembly and includes 21 member states elected for 2-year terms on a rotating basis; the Secretariat, which provides administrative and technical support to the Assembly and the Council. The secretariat is located in Masdar, the low-carbon city under construction outside Abu Dhabi—not part of the original German plan (Röhrkasten and Westphal 2013: 10). As of June 2017, IRENA had held seven Assembly sessions, with all member states participating.

IRENA has been lauded as an unusual success at a time when few other multilateral organizations were established and the institutional landscape for energy issues remained fragmented (Urpelainen and Van de Graaf 2015: 161), much like the situation with international global environmental governance (Van de Graaf 2013b: 64; Biermann et al. 2009a, b; Oberthür 2009). IRENA's membership has grown unusually fast, almost doubling in the first 7 years. At the 2009 founding conference, 75 countries signed on to the Founding Statute; as of September 2017, the membership included 152 states, with a further 28 in the process of acceding (Van de Graaf 2013a: 14; IRENA 2017).

According to the literature, IRENA was deliberately designed as an "epistemic" organization that would facilitate the availability and exchange of information but would neither fund nor implement capital investments in renewables (Urpelainen and Van de Graaf 2015: 168; Röhrkasten 2015; Van de Graaf 2013a; Meyer 2013: 17). IRENA has weak regulatory power and takes a soft-governance approach centered on the positive framing of renewable energy: It argues for renewables without arguing specifically against fossil fuels or nuclear energy (Röhrkasten and Westphal 2013: 9; Meyer 2012).

The literature also notes expectations of considerable demand for the information produced by IRENA (Meyer 2013: 42; Urpelainen and Van de Graaf 2015: 168). Given this expectation and the organization's strongly policy-oriented mandate, one possible criterion of IRENA's success is whether nation-states draw on IRENA in their policymaking on energy issues. Otherwise IRENA risks becoming a merely symbolic 
representation of the desire to promote renewable energy without having much impact on actual energy systems.

As a newcomer on the global energy arena, IRENA must carve out a role for itself in competition with other international energy organizations (Kent 2014). When IRENA was created, it was promoted explicitly as a counterweight to, and remedy for the failings of, the International Energy Agency (IEA), which is seen by some as a bastion of the fossil fuel and nuclear industries (Kottari and Roumeliotis 2013: 239; Van de Graaf 2013a: 16; Van de Graaf and Lesage 2009). Urpelainen and Van de Graaf (2015: 161) maintain that the creation of IRENA served as "a salutary shock to the International Energy Agency and other international organizations, which are keen to capitalize on the growing global interest in renewables." Similarly, Kottari and Roumeliotis (2013: 240) note that "the IEA responded jealously to IRENA's creation." However, beyond such commentary there has been little systematic research on the standing of IRENA compared with the IEA or other international energy organizations.

\section{Our approach}

Much research has focused on explaining the creation of IRENA (Röhrkasten and Westphal 2013; Van de Graaf 2013a; b; Röhrkasten 2015; Urpelainen and Van de Graaf 2015). Less is known about how IRENA has managed to establish itself in the context of other international organizations such as the IEA, or about its visibility at the national level. Therefore, the objective of this article is to make an empirical contribution by assessing how IRENA has established itself in an environment where three other international energy organizations play well-established roles: the IAEA, the IEA, and OPEC. These organizations were selected because they share some basic characteristics with IRENA: They are proper intergovernmental organizations, and they deal exclusively with energy. Together, they form what Abbott et al. (2016: 257) refer to as a "population of organizations." There are many other organizations that address renewable or other types of energy but are not intergovernmental, or that are intergovernmental but address energy in addition to many other issues and thus have a less clear profile.

We approach our objective by addressing the following three research questions: (1) What types of representatives do member states send to IRENA meetings, and what does this reveal about how IRENA is seen as an organization? (2) What financing and human resources does IRENA have access to? (3) How often is IRENA mentioned in national energy policy documents? For each of these questions we include data not only on IRENA, but also on the other international energy organizations.

To answer these three research questions, we assembled several new datasets: on the sector affiliations of the representatives attending IRENA Assembly and Council meetings, on states' voluntary financial contributions to IRENA, and on the budgetary resources and number of staff of the various international energy organizations. We also conducted a word frequency analysis of 639 governmental policy documents from 16 countries, examining how often the IEA and IRENA are mentioned in connection with renewable energy. IEA and IRENA were chosen for this part of the analysis because they are more comparable than the other organizations and are potential competitors in the renewable energy area.

It is early to subject IRENA to such an examination, given that it is still a young organization. However, by conducting this analysis at an early stage, we aim to create a 
baseline against which to measure IRENA's progress, as well as to test various empirical approaches to comparing international energy organizations, or other international organizations, in terms of their capacity and impact on policy-making at the national level. In the future, these approaches might be further developed into a more rigorous comparative system.

The international energy organizations discussed here share the basic characteristics noted above, but they also differ in important ways. Whereas IRENA was founded as recently as in 2009, the others were created several decades earlier. IRENA and the IAEA are open to all UN member states, whereas the IEA accepts only OECD countries and OPEC is in principle open only to major oil exporters (Colgan et al. 2012). The scope of the organizations' mandates also varies. While the IEA caters mainly to oil-importing countries and covers all forms of energy (Wilson 2015; Baccini et al. 2013), the IAEA, IRENA, and OPEC are dedicated to specific forms of energy - though IRENA's renewable energy mandate encompasses various forms of renewable energy. Given these differences, it should be noted that we do not aim at creating a ranking or comparative measurement of the success of the organizations. Instead we have included the above-mentioned organizations because they are key actors in the environment in which IRENA must operate and are thus important in an organizational ecology perspective, as explained in the next section.

\section{Organizational ecology}

This study complements other studies of international energy organizations and global energy governance that focus on, for example, comparing institutional design features of international energy organizations, such as mandate and membership (Wilson 2015) or studies of individual energy organizations (Colgan 2014; Van de Graaf 2012; Florini 2011). Our decision to look at IRENA among other international energy organizations draws inspiration from the organizational ecology approach. The concept of ecology is well established within sociology, in particular when emphasizing the importance of broader organizational environments. Abbott (2005: 252) has described an ecology as being made up of "a set of actors, a set of locations, and a set of links between them." Importantly, competition and coordination among actors are used to define issues and solutions and to determine who has the capacity to address these issues (Abbott 2005). In response to the proliferation of international organizations dealing with climate policy, international relations scholars have recently adopted this approach, which "highlights the constraints and opportunities that institutional environments create" (Abbott et al. 2016: 251). Seabrooke and Sending (2015: 2) see international organizations as "market actors that compete with each other to identify, define and sell solutions to problems." Unlike bureaucracies within nation-states, which may vie for control over an issue-area presumed to be within the authority of the sovereign state, international organizations must "establish a claim to authority over an issue or task while at the same time seeking to establish themselves as the actor of choice for states to invest resources in to govern it" (Seabrooke and Sending 2015: 7).

For analytical purposes, we conceptualize IRENA as having two arenas. The first is an external arena, where IRENA competes with other international organizations to identify, define, and sell solutions to problems. This is in line with the concept of organizational ecology used by Abbott et al. (2016). The second is an internal arena, where actors and 
interests play out within the organization. This draws on Seabrooke and Sending (2015: 11), who elaborate and extend the concept of organizational ecology from the interorganizational space to the space within organizations, positing each international organization as an "arena of action within an open system where different actors may use other types of institutional resources as they attempt to also control issues and construct authority" (see also Scott 1981; Seabrooke and Sending 2015: 2).

The two arenas are not separate, but interlinked. For example, increased involvement of one profession or sector inside the organization can affect its role vis-à-vis other organizations in the external arena. As Seabrooke and Sending (2015: 11-12) put it, "international organizations [...] do not control issues via mandates but through professional expansion and/or coordination." This two-level organizational ecology approach makes it possible to account for the many different actors and interests that play out in interaction with each other within and surrounding an international organization. In the empirical analysis presented in the following sections, we start with the internal arena of IRENA where various member states and types of actors contribute and then examine IRENA as a player in the external arena where it is one organization among others.

\section{IRENA's internal arena}

Central to the sociological version of the organizational ecologies approach is the assumption that professional groups compete and coordinate in seeking to promote issues and define how they are to be dealt with, as well as to determine who is best equipped for dealing with them (Seabrooke and Sending 2015: 11; Abbott 2005). According to Röhrkasten and Westphal (2013: 15), "IRENA since its creation has been dealing with one central cleavage: being a 'development organization' or being a truly 'global promoter' of RE [renewable energy]." IRENA's profile is still a work in progress that could take multiple possible directions.

To understand how IRENA is developing, we examined the kinds of representatives that member states send to the organization's meetings, i.e., which ministries or sectors the representatives come from. This can indicate how the member states view the organization-for instance, whether they focus on its energy, environmental, aid, or diplomatic aspects. These representatives in turn contribute to shaping IRENA's outlook and evolution. For this part of the analysis, we compiled a dataset on all of the 2709 representatives who participated in IRENA's (annual) Assembly and (biannual) Council meetings between 2011 and 2014.

\subsection{Representation: Who attends IRENA meetings?}

Urpelainen and Van de Graaf (2015: 167) use the composition of country delegations to the IRENA Council as an indicator in their work. Our dataset on representation builds on their analysis, but expands the data substantially in four directions: time (from one meeting 1 year to 11 meetings over 4 years), type of meetings (from only Council meetings to also include Assembly meetings), number of delegates (from 71 to 2709), and level of detail (from two to five professional categories).

The choice of delegates representing member states may affect the salience of IRENA when it provides policy advice and services for national governments. For example, if delegates tend to be drawn from NGOs, upon returning home they may have less impact on 
government policy than if government staff themselves were involved in the international organization. Similarly, if representatives come from energy ministries, there may be greater saliency within the domestic energy sector; by contrast, if delegations are filled with representatives of environmental or foreign ministries, energy ministries may be less attentive than they would be otherwise. If there are many representatives from development agencies, that may help IRENA play an important role in development aid to the energy sector, but the organization may have less impact on the development of renewable energy in industrialized countries.

As Fig. 1 shows, diplomats and representatives from energy institutions predominated in IRENA meetings. Thus, Urpelainen and Van de Graaf's (2015: 167) finding - that IRENA has not been "grabbed" by environmental ministries and other national-level environmental institutions to the detriment of energy ministries-is confirmed. As we argue above, the more representatives from governmental energy bodies participate in IRENA meetings, the more likely is IRENA to be utilized as a resource by those energy bodies and thus to have an impact on policy-making at the national level. However, Fig. 1 also shows approximately as many diplomatic representatives as representatives of energy ministries, though the latter have been catching up. The strong presence of diplomats may be because there were many governance and organizational issues to address in connection with the first phase of the organization. It may also be because poorer states lack the resources to send personnel other than diplomats who are already present in the region. In any case, this aspect may have the following implications regarding the impact of IRENA on national policy: The more diplomats, the weaker the reverse linkages to the national level as diplomats do not normally implement energy policy in their home countries. Even in cases where diplomats specialize in energy issues, this is normally at the international rather than the domestic level. Although there are important connections between the national and international levels of energy governance, especially in the areas of greenhouse gas emissions and nuclear non-proliferation, diplomats do not normally manage domestic energy policy.

Some actors have seen IRENA as a type of aid organization for the transfer of renewable energy technology to developing countries, and not as an organization for promoting renewable energy in all countries (Röhrkasten and Westphal 2013), but very

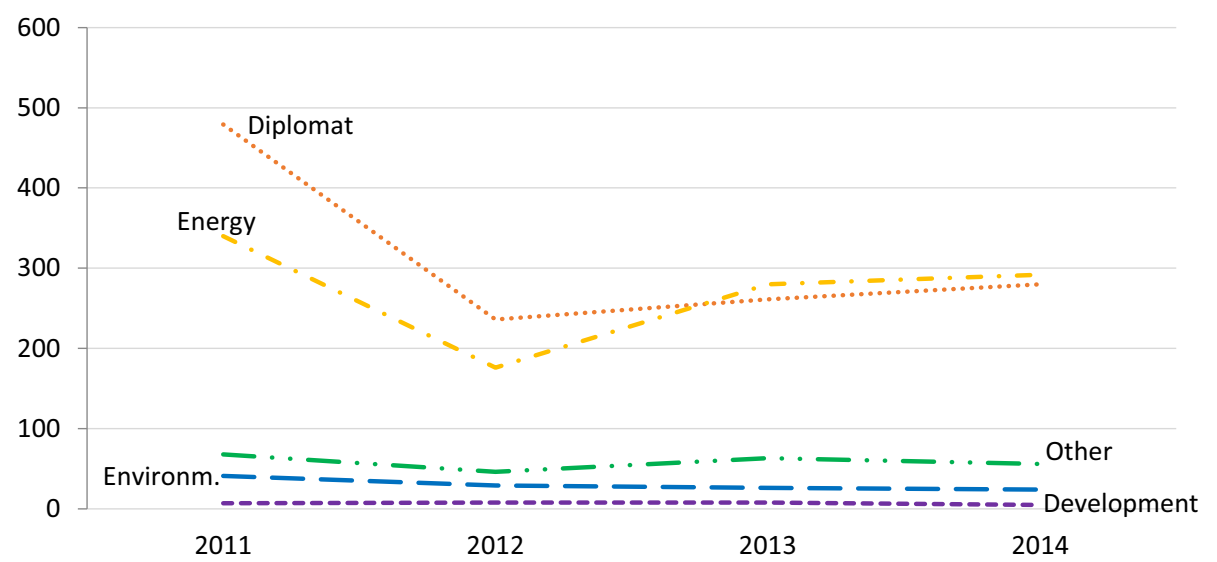

Fig. 1 Number of representatives attending IRENA Assembly and Council meetings, by ministry or other type of government institution 
few representatives of development agencies or ministries have attended IRENA Assembly and Council meetings. Of the five categories included in Fig. 1, personnel from the development sector are consistently the smallest group. It is possible that some in the category "diplomats" are in fact staff involved in development aid, but this error is likely to be small, as we have examined not only institutional affiliations but also job titles. Thus, in response to the question raised by Röhrkasten and Westphal back in 2013, we may conclude that IRENA is not viewed as a type of specialized development agency (Röhrkasten and Westphal 2013: 15).

Another pattern observed is that the overall number of representatives at Assembly and Council meetings was high in 2011 and then declined and stabilized at a lower level. This finding probably indicates special interests in connection with the founding of IRENA.

Finally, some caveats are appropriate. Our analysis does not distinguish between varying sizes of national delegations, as our concern is with the overall representation of different sectors at IRENA meetings, not the representations of different countries as such. Obviously, countries that send more representatives will be able to exert greater influence on the content of meetings and the development of the organization, as well as having more potential backward linkages to domestic policy—but our focus is on the sum of the representatives that make up the organization.

It is also worth noting that not all countries have a dedicated energy ministry. In many of the countries that lack such a ministry, energy issues are handled by a sub-unit of a ministry of economic development or the like. In our dataset those institutions were included in the category "Other." Thus, it is possible that the representation of government representatives handling domestic energy issues is even greater than we surmise.

\subsection{Financial contributions}

Next, we assess how committed the member states are to IRENA by looking at their financial contributions over time. IRENA receives two types of financial contributions from member states: assessed and voluntary. Assessed contributions are fixed according to GDP and thus reveal little about interest, apart from the fact that these states have chosen to become members of the organization in the first place. Voluntary contributions, however, may be an indication of commitment to IRENA. We assume that the greater the voluntary financial contributions from a given state, the more engaged is it in the organization. This part of the analysis is based on another new dataset compiled for the purpose of this study: on member states' voluntary financial contributions between 2011 and 2014.

Figure 2 shows that, compared with the large number of countries that joined IRENA, few countries made voluntary contributions to the organization during its first few years of existence. Voluntary contributions were heavily dominated by Germany and the United Arab Emirates (UAE) - the two countries where the IRENA institutions are based and which therefore have a financial interest in boosting the organization (because funds will flow back into their own economies), as well as a symbolic self-interest (because the organization's success reflects on their efforts to promote it). IRENA headquarters are located in Masdar City in the UAE, and the IRENA Innovation and Technology Centre (IITC) is in Bonn, Germany. According to Van de Graaf (2013b), the decision on location and financial support involved an explicit quid pro quo.

On the one hand, that so few countries have made substantial contributions means that IRENA so far has failed to realize its full potential. On the other hand, it also means that IRENA has considerable scope for increasing voluntary contributions and expanding its overall budget. Moreover, ministerial budgetary and decision-making cycles may delay 


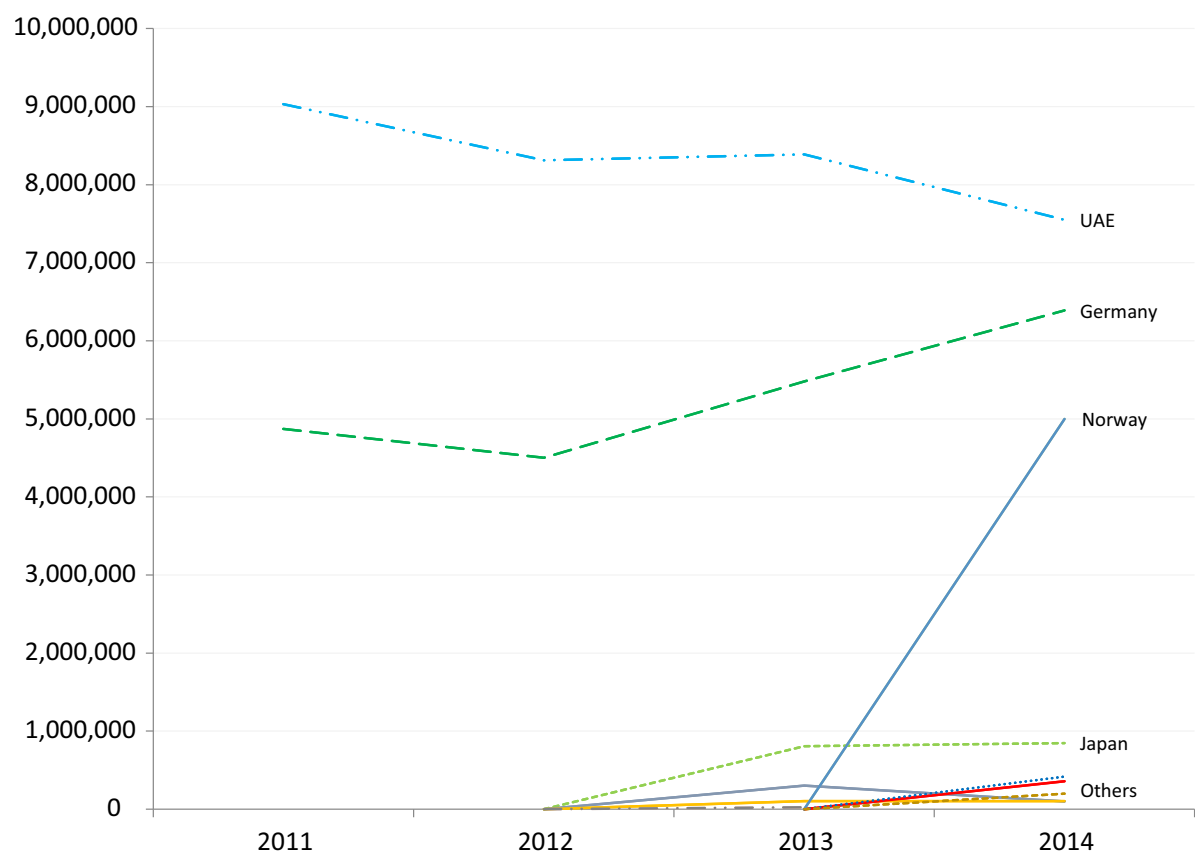

Fig. 2 Voluntary contributions to IRENA by country, in USD. Data sources: IRENA (2013a, b, 2014)

funding flows to a relatively new organization such as IRENA. In 2013 and especially 2014, more countries started contributing. Most countries still contribute relatively small sums, but both the sums and the number of countries contributing could grow rapidly.

As Fig. 2 shows, Norway's contribution suddenly increased from 0 in 2013 to USD 5 million in 2014. Part of the underlying reason is that Norway is a wealthy country committed to spending $1 \%$ of its gross national income on development aid, and its contributions to IRENA are classified as development aid. In addition, Norway wants to contribute to climate change mitigation but has high domestic costs, and has therefore tended to search for opportunities to do so internationally. This is one reason why Norway has invested considerable funds in the REDD+ rainforest protection program, which channels funding to countries where the money is expected to contribute more to climate change mitigation than if it were spent in the donor country (Carr 2015).

\section{IRENA's external arena}

As an actor in the multilateral marketplace, IRENA must compete with other international organizations and actors in defining problems and proposing solutions (Seabrooke and Sending 2015: 2). In the field of international energy, the best-established organizations are the International Atomic Energy Agency (IAEA), the International Energy Agency (IEA), and the Organization of the Petroleum Exporting Countries (OPEC). Thus these organizations make up the organizational ecology that IRENA must relate to. Obviously, the IAEA and OPEC do not focus on renewable energy. As for the IEA, it was originally established to provide emergency mechanisms to protect against oil supply shortages. Over 
time, it has become the leading international institution for international energy market analysis and related policy advice, while retaining its focus on oil and other fossil fuels. It has also gradually become more active in the field of renewable energy, establishing a Working Party on Renewable Energy Technologies in 1982 and a dedicated renewable energy unit in 1999 (Van de Graaf 2013b). However, it still includes only OECD countries as member states.

Urpelainen and Van de Graaf (2015: 171) take the IEA's increasing attention to renewable energy as evidence of IRENA's influence, arguing that the creation of IRENA has made the IEA more competitive in this area. However, they do not quite prove that the IEA's growing interest in renewables is due to the creation of IRENA. The two developments coincided in time, but that may have been due to the global surge in interest in renewable energy rather than a direct causal linkage between the two. To get a clearer idea of IRENA as an actor among other international energy organizations, we examine its levels of financial and human resources, juxtaposing them with those of the other international energy organizations.

\subsection{Proximity search for IEA and IRENA and renewable energy in national policy documents}

If a policy-oriented multilateral organization such as IRENA plays an important role in policy-making at the national level, that organization should be mentioned in government policy documents. The more that a given state pays attention to the recommendations of an international organization, respects its views, uses its reports and data, and participates actively in its work, the more likely is that state to refer to the organization in its policy documents. As IRENA gains traction and begins to play a role alongside the other international energy organizations, its name should appear more frequently in national policy documents.

However, this assumption may not always hold true-in some cases, an organization may be mentioned because of scandals or conflicts. There also ambivalent cases. For example, if a report refers to "OPEC production," one could argue that this is a reference to the oil production of the countries that are members of OPEC rather than to OPEC as an organization; or one could argue that the only reason for referring to that decidedly disparate group of oil producers is precisely that OPEC as an organization brings them together and (attempts to) coordinate their oil production. The connection between references to organizations in documents and their actual policy impact is therefore not definite, and we include this metric solely for explorative empirical purposes.

We compiled a primary dataset of 639 governmental policy documents related to energy from the period 2011-2014 from the following 16 countries: Australia, Austria, Bangladesh, Canada, China, Germany, Ireland, Jamaica, Japan, Kenya, New Zealand, Nigeria, Norway, South Africa, Sweden, and the UK. The documents are white papers, green papers, framework programs and similar documents that represent official government policy.

We conducted proximity searches for "IEA" and "renewable" to identify cases where the IEA was mentioned specifically in connection with renewable energy. These searches had a proximity range of 20 words; thus, any occurrence of "IEA" and "renewable" 20 or fewer words apart was counted a hit. The proximity search was case-sensitive, and was rerun with "renewable" in four languages and in lower and upper case: in English, German, Norwegian, and Swedish ("renewable," "Renewable," "fornybar," "förnybar," "erneuerbar," "Erneuerbar"). 
For IRENA, such a search would be difficult, because the word "renewable" is included in the organization's name itself. However, with IRENA it could be argued that all occurrences are relevant to renewable energy, as the organization is dedicated to its promotion.

We then calculated the ratio of occurrences of "IRENA" to proximity search hits for "IEA" and "renewable energy." As shown in Fig. 3, IRENA appeared more and more often than did the IEA in connection with renewable energy in government policy documents. Although this result should not be over-interpreted, it may indicate that IRENA is playing a steadily greater role in regard to renewable energy, reaching parity with the IEA in 2014. Thus, although the IEA may still get much more attention regarding other energy topics, IRENA may be taking over the renewable energy niche. On the other hand, the IEA, which has only 29 member countries and deals with all types of energy, is still receiving as much attention related to renewable energy as IRENA, which has 150 member countries and deals exclusively with renewable energy. In this perspective, IRENA still has some way to go.

To supplement this quantitative content analysis, we conducted a qualitative examination of the search results in the government documents of five countries where access to documents was particularly good (Australia, Canada, Ireland, Norway, Sweden). The aim was to determine the contexts in which IRENA is mentioned in national policy documents and how governments use it as a resource.

Of course, the mere occurrence of "IRENA" in a government document does not prove that IRENA plays a significant role in policy-making. Of the five countries whose government documents we examined qualitatively, only in the Australian documents was IRENA cited as a source of information. In the documents from the other countries, the governments simply noted that IRENA had been established, that their country had joined it, ratified accession, or the like. For example, Ireland's EirGrid (2010: 24) reported: "The 2009 decision to establish the International Renewable Energy Agency (IRENA) is

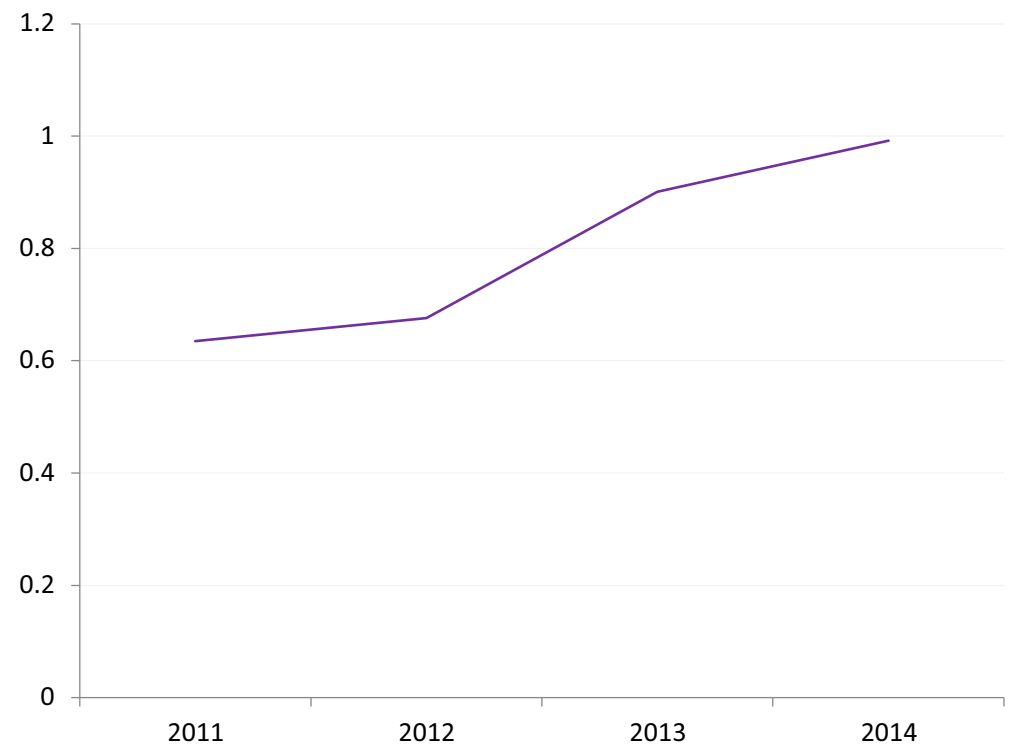

Fig. 3 Ratio of occurrences of "IRENA" to "IEA AND renewable energy" 
evidence of this new trend. IRENA is the first international organization commissioned to conduct research, provide advice and promote technological developments in the renewable energy sector." Similarly, the Norwegian Ministry of Foreign Affairs (2009: 131) wrote in a white paper: "At the founding conference in Bonn on 26 January 2009, Norway joined the new international organization for renewable energy [...]. The purpose of IRENA is to promote the use of renewable energy internationally, especially in developing countries."

Some policy documents simply listed IRENA as one among many forms of international energy cooperation. For example, as one Swedish document stated, "At the global level there are cooperative arrangements such as IRENA, which was established in 2009 and which will promote renewable energy" (Government of Sweden 2009: 42). The Canadian documents had no references to IRENA at all-hardly surprising, as Canada is neither a member of IRENA nor in the process of joining the organization.

In fact, the lack of relevant qualitative information for analyzing the substance of references to IRENA is a finding in itself: If IRENA had had a major policy impact, this material would have provided for a more interesting qualitative analysis. In contrast, a reference to the IEA is more likely to indicate genuine policy impact, because that organization has existed much longer, and there is rarely any point in mentioning it unless it has produced something relevant. As IRENA's membership base becomes more complete and fewer new countries join the organization, the number of superficial IRENA occurrences will decline - and the organization will have to strive to replace them with mentions of real policy impact.

All the same, this comparison of references between the IEA and IRENA is biased in favor of the IEA and the other older organizations, which have had a head start and are sometimes referred to in the context of data and documents that they produced before IRENA even came into existence. However, our comparison is not meant as a contest, but as an exploration of the international context for the early evolution of IRENA. Put differently: there is much room for IRENA to grow rapidly in the coming years, as it accumulates documents and data, and national governments have more time to digest and use them.

\subsection{Budget and staffing}

As IRENA works to establish itself in relation to other international energy organizations and nation-states, it depends on access to resources - both financial and human. Resources can play three types of roles. First, they are a means of achieving an impact. The more resources an organization has, the more it can do and the greater its potential impact. Employees can also potentially create new linkages to their home country, as well as to other organizations and organizational units where they have worked or with which they are connected. Rising staff numbers may thus also enhance IRENA's policy impact. Second, and conversely, resources are possible indicators of success, i.e., an effect as well as a cause of impact. When states contribute resources to an organization, that indicates a vote of confidence. Thus, the more resources an organization such as IRENA has, the more successful it may already be. Third, and by extension, resources are potential objects of competition between the international organizations.

First, we compare the budgets of the four international energy organizations over 5 years, expanding on Urpelainen and Van de Graaf's (2015: 170) 1-year, two-organization comparison. We employ this metric as another window on IRENA's place in the 
family of international energy organizations, as well as an indicator of member state engagement in IRENA compared with the other organizations.

Figure 4 shows that IRENA's budget is similar to that of the IEA. This finding is mirrored in Fig. 5, which shows numbers of employees.

IEA member states contribute many seconded staff, who are paid directly by these member states and not through the IEA budget. Staff numbers, compared with budget figures, may thus be a better measure of the strength and resource bases of the organizations. Figure 5 shows that IRENA is by far the smallest of the four international energy organizations in terms of staff, but recruitment is still ongoing. The relatively low number of staff at IRENA — under a third of that of the IEA — probably means that IRENA has less impact at the national policy level than it might otherwise have.

However, the differences between the mandates of the organizations make it difficult to compare them directly in terms of funding and staffing. IRENA covers renewable energy only and OPEC deals with oil only, while the IEA covers all types of energy. As for the IAEA, much of its staffing and funding are related to nuclear security and non-proliferation, which may or may not be considered inherent aspects of nuclear power.

Finally, it is worth noting that there is no one-to-one relationship between the impact of an organization such as IRENA and the quantities of funding and staff available to that organization. Much depends on how effectively the funds are spent and the staff employed. This can be illustrated by an example from another part of the energy sector, oil companies, where privately owned companies produce far more barrels per employee than do most nationally owned oil companies, often despite the national oil companies having privileged access to oilfields. That being said, the possibility of such inefficiencies does not mean that funding and staff are without relevance to understanding an organization's clout.

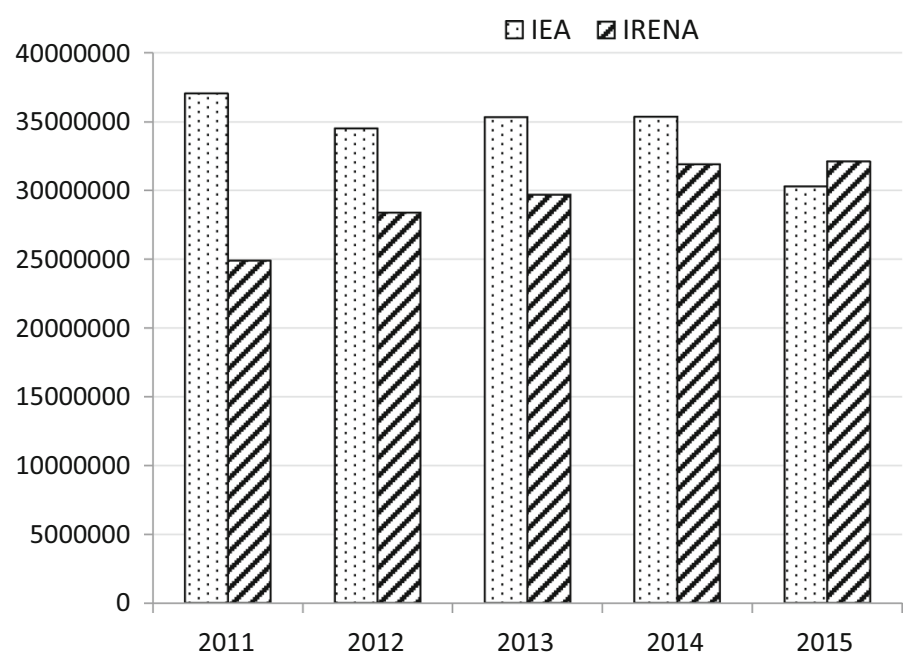

Fig. 4 Size of budgets of IEA and IRENA, in USD 


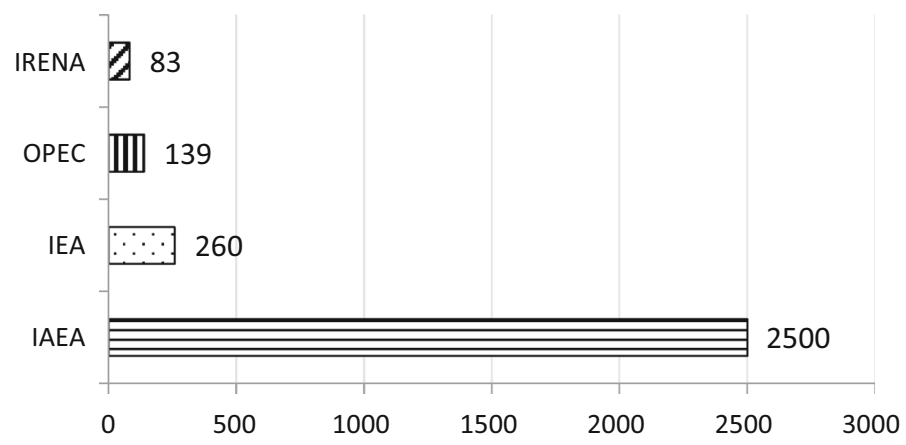

Fig. 5 Number of employees, international energy organizations, 2015. Data sources: IAEA (2016), IEA (2016), IRENA (2013b: 4), OPEC (2016), Urpelainen and Van de Graaf (2015: 160)

\section{Conclusions}

At the beginning of this article, we set out to assess how IRENA established itself during the first years of its existence, in a context where three other energy organizations were already playing well-established roles. Drawing on an organizational ecology approach we identified an internal and an external arena of IRENA and posed three research questions: (1) What types of representatives do member states send to IRENA meetings, and what does this reveal about how IRENA is seen as an organization? (2) What financing and human resources does IRENA have access to? (3) How often is IRENA mentioned in national energy policy documents?

Analysis of the composition of state delegations indicated that member states seem to have defined renewable energy, in the context of IRENA, as an energy issue. Despite the strong linkages to climate change and development issues, the choice of delegates to IRENA meetings indicates that IRENA is viewed primarily as an energy organization. With more personnel from governmental energy bodies participating in IRENA meetings, IRENA is more likely to be utilized as a resource by those energy bodies in their domestic policy-making.

Our voluntary contributions indicator showed that, during the first years of IRENA's existence, significant funding came only from the primary host state (the United Arab Emirates) and the main founding state and secondary host state (Germany). Subsequently, other states started contributing, but their voluntary contributions remained small and came from only a few member states. This finding could indicate that IRENA has yet to engage its member countries properly; or, in a more positive perspective, it may be interpreted as showing that there is great scope for increasing voluntary contributions to IRENA. In future research, it would be advisable to add further qualitative analysis of how various countries view IRENA, particularly those that have made voluntary contributions. Do they seek to push IRENA in any direction-and, if so, how successfully? A related question concerns how views of IRENA are manifested at the national level: how do various domestic agencies treat IRENA?

Our analysis of the financial and human resources available to IRENA and the other international energy organizations examined here showed that IRENA's financial resources were almost equal to those of the IEA, but that-owing to extensive secondment of staff from member states to the IEA-IRENA had less than a third of the human resources. However, we also noted that such information provides a weak basis for comparison of the 
organizations, as they have such different histories and mandates. Rather, it is helpful for understanding, in an organizational ecology perspective, the environment in which IRENA must operate.

Our proximity search for occurrences of IEA and IRENA in connection with "renewable energy" in policy documents from 16 countries found that IRENA has rapidly caught up with IEA in the renewable energy niche, achieving parity in 2014.

These empirical results can provide some pointers for anyone interested in promoting IRENA and/or renewable energy: the organization needs more funding and more staff, and these staff need to produce more concrete output relevant for energy policy-making at the national level. And indeed, the prospects appear to be good. Against the backdrop of the 2015 Paris Agreement and the UN General Assembly's adoption of the Sustainable Development Goals, renewable energy seems set to grow in importance, and along with it, so will IRENA.

In its membership criteria and focus on renewable energy, IRENA enjoys several important comparative advantages over other international energy organizations in the evolving global energy landscape. The IEA covers all energy types but is open only to OECD member states. The IAEA is open to all countries but addresses a type of energy that many of them do not have access to. OPEC's membership consists solely of major non-Western oil producers. In contrast, IRENA is open to all countries in the world and deals with a type of energy that is accessible to all countries in some form (such as solar, wind or hydroelectric power). Thus, both the IEA's sluggishness in taking renewable energy seriously and the failure to create a global energy organization may prove favorable for global governance of renewable energy. Rather than the IEA taking on a leading role in renewable energy but accepting only OECD countries as members, or a global energy organization being created but having to address all forms of energy and the associated interest groups, IRENA has the chance to move forward with a global membership base while focusing exclusively on renewables.

Finally, that the UEA should seek to become the host country for IRENA's headquarters may have come as a surprise to the Germans and other backers of IRENA's creation, because the UEA is a major oil producer located at the heart of the world's largest petroleum province. However, also this could turn out to be a blessing in disguise. Germany and many other West European countries were already onboard: and locating the headquarters elsewhere has made it possible to reach out to other parts of the world.

Acknowledgements This article is a product of a research project carried out jointly by the Swedish Institute of International Affairs and the Norwegian Institute of International Affairs and funded by the Swedish Energy Agency. It should however not be taken to represent the views of the Swedish Energy Agency, and the publication points belong exclusively to the authors. The authors are grateful to Johan Eriksson and Jakub Godzimirski for commenting on earlier drafts, as well as to the two anonymous reviewers of INEA for their advice.

Open Access This article is distributed under the terms of the Creative Commons Attribution 4.0 International License (http://creativecommons.org/licenses/by/4.0/), which permits unrestricted use, distribution, and reproduction in any medium, provided you give appropriate credit to the original author(s) and the source, provide a link to the Creative Commons license, and indicate if changes were made.

Funding Funding was provided by the Swedish Energy Agency (Grant No. 38068-1) and the Russcasp project, which is financed by the Petrosam program of the Research Council of Norway. 


\section{References}

Abbott, A. (2005). Linked ecologies: States and universities as environments for professions. Sociological Theory, 23(3), 245-274.

Abbott, K. W., Green, J. F., \& Keohane, R. O. (2016). Organizational ecology and institutional change in global governance. International Organization, 70(2), 247-277.

Andrews-Speed, P., \& Shi, X. (2016). What role can the G20 play in global energy governance? Implications for China's presidency. Global Policy, 7(2), 198-206.

Baccini, L., Lenzi, V., \& Thurner, P. W. (2013). Global energy governance: Trade, infrastructure, and the diffusion of international organizations. International Interactions, 39(2), 192-216.

Bazilian, M., Outhred, H., Miller, A., \& Kimble, M. (2010). Opinion: An energy policy approach to climate change. Energy for Sustainable Development, 14(4), 253-255.

Biermann, F., Davies, O., \& van der Grijp, N. (2009a). Environmental policy integration and the architecture of global environmental governance. International Environmental Agreements, 9, 351-369.

Biermann, F., Pattberg, P., van Asselt, H., \& Zelli, F. (2009b). The fragmentation of global governance architectures: A framework for analysis. Global Environmental Politics, 9(4), 14-40.

Carr, M. (2015). Norway bets cutting pollution abroad is an easier battle. http://www.bloomberg.com/news/ articles/2015-03-12/norway-bets-pollution-abroad-an-easier-battle-carbon-climate. Accessed November $11,2016$.

Colgan, J. D. (2014). The emperor has no clothes: The limits of OPEC in the global oil market. International Organization, 68(3), 599-632.

Colgan, J. D., Keohane, R. O., \& Van de Graaf, T. (2012). Punctuated equilibrium in the energy regime complex. The Review of International Organizations, 7(2), 117-143.

Downie, C. (2015). Global energy governance in the G-20: States, coalitions, and crises. Global Governance, 21(3), 475-492.

EirGrid. (2010). Annual renewable report: Powering a sustainable future. Dublin: EirGrid.

Federal Foreign Office [Germany]. (2014). IRENA: Promoting renewable energy worldwide. http://www. auswaertiges-amt.de/EN/Aussenpolitik/GlobaleFragen/Energie/IRENA-Gruendung_node.html. Accessed November 3, 2016.

Florini, A. (2011). The International Energy Agency in global energy governance. Global Policy, 2(s1), 40-50.

Florini, A., \& Dubash, N. K. (2011). Introduction to the special issue: Governing energy in a fragmented world. Global Policy, 2(s1), 1-5.

Florini, A., \& Sovacool, B. K. (2009). Who governs energy? The challenges facing global energy governance. Energy Policy, 37, 5239-5248.

Government of Sweden. (2009). Utvärdering av insatserna för forskning och innovation inom energiområdet. Regeringens skrivelse 2009/10:168. http://www.regeringen.se/contentassets/ b602841cbca6447a89f908a65872f24e/utvardering-av-insatserna-for-forskning-och-innovation-inomenergiomradet-skr.-200910168. Accessed March 5, 2016.

Hirschl, B. (2009). International renewable energy policy: Between marginalization and initial approaches. Energy Policy, 37(11), 4407-4416.

IAEA. (2016). Secretariat. https://www.iaea.org/about/staff. Accessed March 7, 2016.

IEA. (2016). Member countries. http://www.iea.org/aboutus. Accessed March 7, 2016.

IRENA. (2013a). Audited financial statements of the Agency for 2011. http://www.irena.org/ DocumentDownloads/2013/Assembly/A_3_11_Financial\%20Statements_2011.pdf. Accessed March 7, 2016

IRENA. (2013b). Report of the Director-General on the implementation of the work programme and budget for 2012. https://www.irena.org/DocumentDownloads/2013/Assembly/A_3_2_2012\%20Annual\% 20Report.pdf. Accessed March 7, 2016.

IRENA. (2014). Report of the Director-General on the implementation of the work programme and budget for 2013. http://www.irena.org/DocumentDownloads/2014/2014Assembly/A_4_2_Annual\%20Report. pdf. Accessed March 7, 2016.

IRENA. (2017). IRENA membership. http://www.irena.org/Menu/Index.aspx?mnu=Cat\&PriMenuID= 46\&CatID=67. Accessed November 1, 2016.

Karlsson-Vinkhuyzen, S. I. (2010). The United Nations and global energy governance: Past challenges, future choices. Global Change, Peace \& Security, 22(2), 175-195.

Kent, A. (2014). Implementing the principle of policy integration: Institutional interplay and the role of international organizations. International Environmental Agreements, 14, 203-224. 
Kottari, M., \& Roumeliotis, P. (2013). Renewable energy governance challenges within a "puzzled" institutional map. In E. Michalena \& J. Maxwell (Eds.), Renewable energy governance (pp. 233-248). London: Springer.

Leal-Arcas, R., \& Filis, A. (2013). The fragmented governance of the global energy economy: A legalinstitutional analysis. The Journal of World Energy Law \& Business, 6(4), 348-405.

Lesage, D., Van de Graaf, T., \& Westphal, K. (2009). The G8's role in global energy governance since the 2005 Gleneagles summit. Global Governance, 15(2), 259-277.

Meyer, T. (2012). Global public goods, governance risk, and international energy. Duke Journal of Comparative and International Law, 22, 319-348.

Meyer, T. (2013). Epistemic institutions and epistemic cooperation in international environmental governance. Transnational Environmental Law, 2(2), 15-44.

Norwegian Ministry of Foreign Affair. (2009). St.meld. nr. 15 (2008-2009) [White Paper], Interesser, ansvar og muligheter: Hovedlinjer $i$ norsk utenrikspolitikk. https://www.regjeringen.no/no/ dokumenter/stmeld-nr-15-2008-2009-/id548673/?ch=1\&q. Accessed March 6, 2016.

Oberthür, S. (2009). Interplay management: Enhancing environmental policy: Integration among international institutions. International Environmental Agreements, 9, 371-391.

Oberthür, S. (2016). Where to go from Paris? The European Union in climate geopolitics. Global Affairs, 2(2), 119-130.

OPEC. (2016). Employment information. http://www.opec.org/opec_web/en/employment/55.htm. Accessed March 7, 2016.

Parthan, B., Osterkorn, M., Kennedy, M., Bazilian, M., \& Monga, P. (2010). Lessons for low-carbon energy transition: Experience from the Renewable Energy and Energy Efficiency Partnership (REEEP). Energy for Sustainable Development, 14(2), 83-93.

Röhrkasten, S. (2015). Global governance on renewable energy: Contrasting the ideas of the German and the Brazilian governments. Berlin: Springer.

Röhrkasten, S., \& Westphal, K. (2013). IRENA and Germany's foreign renewable energy policy. Working Paper FG 8. Berlin: Stiftung Wissenschaft und Politik, Global Issues Division.

Rowland, I. H. (2005). Renewable energy and international politics. In P. Dauvergne (Ed.), Research in global environmental politics: History and trends: Handbook of global environmental politics (pp. 78-94). Cheltenham: Edward Elgar.

Scott, W. R. (1981). Organizations: Rational, natural, and open systems. Upper Saddle River, NJ: Prentice Hall.

Seabrooke, L., \& Sending, O. J. (2015). Open systems of international organization. GR:EEN Working Paper No. 51, Centre for the Study of Globalisation and Regionalisation, University of Warwick. www. greenfp7.eu/papers/workingpapers. Accessed March 5, 2016.

Urpelainen, J., \& Van de Graaf, T. (2015). The International Renewable Energy Agency: A success story in institutional innovation? International Environmental Agreements: Politics, Law and Economics, 15(2), 159-177.

Van de Graaf, T. (2012). Obsolete or resurgent? The International Energy Agency in a changing global landscape. Energy Policy, 48, 233-241.

Van de Graaf, T. (2013a). Fragmentation in global energy governance: Explaining the creation of IRENA. Global Environmental Politics, 13(3), 14-33.

Van de Graaf, T. (2013b). The politics and institutions of global energy governance. Basingstoke: Palgrave Macmillan.

Van de Graaf, T., \& Lesage, D. (2009). The International Energy Agency after 35 years: Reform needs and institutional adaptability. Review of International Organizations, 4(3), 293-317.

Van de Graaf, T., \& Westphal, K. (2011). The G8 and G20 as global steering committees for energy: Opportunities and constraints. Global Policy, 2(1), 19-30.

Wilson, J. D. (2015). Multilateral organizations and the limits to international energy cooperation. New Political Economy, 20(1), 85-106. 